\title{
W sprawie doktoratów w projektach założeń Prawa szkolnictwa wyższego (Ustawa 2.0)
}

1. W Polsce stopień doktora jest nadawany od pierwszych lat po uzyskaniu niepodległości. Oczywiście, warunki prowadzące do jego nabycia w okresie 1920-2017 były różne. Zmianom podlegały instytucje uprawnione do jego nadawania oraz warunki wymagane do nabycia uprawnienia w tym zakresie. Przez cztery i pół dekady lat (1920-1965) nadawanie stopnia doktora normowały wyłącznie przepisy dotyczące szkół wyższych, od marca 1965 r. zaś ustawa o stopniach naukowych i tytułach naukowych ${ }^{1}$.

W tym czasie ranga stopnia doktora w ścieżce kariery naukowej nie była wartością stałą. W II Rzeczypospolitej oraz w pierwszych latach Polski Ludowej stopień doktora był wyższym stopniem naukowym² ${ }^{2}$. Takiej

${ }^{1}$ Ustawa z dnia 31 III 1965 r. o stopniach naukowych i tytułach naukowych (Dz.U. Nr 14, poz. 101). Ustawę tę uchylono Ustawą z dnia 12 IX 1990 r. o tytule naukowym i stopniach naukowych (Dz.U. Nr 65, poz. 386). Ustawę z 1990 r. uchylono z kolei Ustawą z dnia 14 III 2003 r. o stopniach naukowych i tytule naukowym oraz o stopniach i tytule w zakresie sztuki (Dz.U. Nr 65, poz. 595), wielokrotnie zmienianą.

2 Tę rangę doktoratów w II Rzeczypospolitej wyznaczały dwie ustawy o jednobrzmiącym tytule - o szkołach akademickich pierwsza z dnia 13 VII 1920 r. (Dz.U. Nr 72, poz. 494 ze zm.), druga z dnia 15 III 1933 r. (Dz.U. Nr 29, poz. 247 ze zm.), ponadto w pierwszych latach Polski Ludowej Dekret z dnia 28 X 1947 r. o organizacji nauki i szkolnictwa wyższego (Dz.U. Nr 66, poz. 415). Szerzej o doktoratach z tych lat i ich nostryfikacji zob.: K. Wojtczak, O stopniach naukowych $i$ veniam legendi w II Rzeczypospolitej (Czesść I), "Studia Prawa Publicznego" 2014, nr 3(7), s. 53-66; eadem, O stopniach naukowych $i$ veniam legendi w II Rzeczypospolitej (Część II), "Studia Prawa Publicznego” 2014, nr 4(8), 
też rangi stopniem był stopień naukowy doktora nauk przewidziany ustawą z $1951 \mathrm{r}^{3}$ Nie były to jednak stopnie naukowe porównywalne ani w zakresie wymagań stawianych przed instytucjami wnioskującymi o prawo do ich nadawania, ani w zakresie uprawnień osób je nabywających, statuujących w konsekwencji ich awans naukowy i pozycję zawodową ${ }^{4}$ Sedno ówczesnych rozwiązań prawnych sprowadzało się do tego, że nadaniu stopnia naukowego doktora, jako wyższego stopnia naukowego, towarzyszyły zarazem, z wyjątkiem lat 1951-1958, rozwiązania przewidujące przeprowadzanie postępowań habilitacyjnych prowadzących w II Rzeczypospolitej do veniam legendi, w pierwszych latach Polski Ludowej - do prawa nauczania, od 1958 r. do nabycia stopnia i tytułu naukowego docenta ${ }^{5}$, od 1968 r. - do stopnia naukowego doktora habilitowanego ${ }^{6}$.

Nie przez cały okres objęty analizą stopień doktora był wyższym stopniem naukowym. Zmianę tego stanu rzeczy, sprowadzającą ten stopień naukowy do stopnia niższego, wprowadziła ustawa z 1958 r. $^{7}$ I ten stan nie uległ zmianie w kolejno przyjmowanych rozwiązaniach prawnych aż po czasy współczesne. W roku 2016 Ministerstwo Nauki i Szkolnictwa Wyższego zapowiedziało szeroko zakrojone zmiany w sektorze szkolnictwa wyższego i nauki. Do przygotowania projektów założeń do Ustawy 2.0 wytypowało, w drodze konkursowej, trzy niezależne zespoły $^{8}$. Każdy z nich przedmiotem swych badań i proponowanych

s. 11-22; eadem, W kwestii wyższego stopnia naukowego doktora w Polsce Ludowej, "Studia Prawa Publicznego" 2016, nr 4(16), s. 33-46.

${ }^{3}$ Ustawa z dnia 15 XII 1951 r. o szkolnictwie wyższym i o pracownikach nauki (Dz.U. $1952 \mathrm{Nr} 6$, poz. 38 ze zm.).

${ }^{4} \mathrm{O}$ stopniu doktora nauk w latach 1951-1958 zob. K. Wojtczak, W kwestii wyższego stopnia naukowego doktora..., s. 46-57.

${ }^{5} \mathrm{~K}$. Wojtczak, O stopniach naukowych i veniam legendi $w$ II Rzeczypospolitej (Część II), s. 22-31; eadem, Habilitacje w Polsce Ludowej. Czesść 1. Warunki i przebieg habilitacji w prawie szkół wyższych, "Studia Prawa Publicznego” 2017, nr 1(17), s. 25-61.

${ }^{6}$ Szerzej zob. K. Wojtczak, Habilitacje w Polsce Ludowej. Czesść 2. Warunki i przebieg habilitacji w prawie o stopniach i tytułach naukowych, "Studia Prawa Publicznego" 2017, nr 2(18), s. 43-81.

${ }^{7}$ Ustawa z dnia 5 XI 1958 r. o szkołach wyższych (Dz.U. Nr 68, poz. 336 ze zm.).

${ }^{8}$ Propozycja założeń do ustawy regulującej system szkolnictwa wyższego, H. Izdebski (kierownik projektu), A. Świergiel, P. Chmielnicki, P. Ruszkowski, W. Misiąg, A. Kiebała, J. Zieliński, Uniwersytet SWPS, Warszawa 2017, dalej „Projekt pierwszy” lub „zespół pierwszy; Projekt założeń do ustawy Prawo o szkolnictwie wyższym, M. Kwiek z Zespołem: D. Antonowicz, J. Brdulak, M. Hulicka, T. Jędrzejewski, R. Kowalski, E. Kulczycki, K. Szadkowski, A. Szot, J. Wolszczak-Derlacz, Uniwersytet im. Adama Mickiewicza w Poznaniu, Poznań 2016, dalej „Projekt drugi” lub „zespół drugi”; PLUS RATIO QUAM 
rozwiązań objął także sprawy dotyczące prawa nadawania stopnia doktora oraz studiów doktoranckich. Nie czekając na sporządzenie rządowych projektów ustaw dotyczących sektora szkolnictwa wyższego, w tym nadawania stopni naukowych, Sejm RP w kwietniu 2017 r. uchwalił ustawę zmieniającą ustawę z 2003 r. o stopniach naukowych i tytule naukowym oraz o stopniach i tytule w zakresie sztuki ${ }^{9}$, wdrażającą nowe rozwiązania w zakresie przewodów doktorskich i studiów doktoranckich.

Skłania to do pytania o proponowane projektami założeń zmiany w zakresie: (1) nadawania stopnia doktora, (2) istoty nowych doktoratów (naukowych vs. zawodowych) i celu ich wprowadzenia, a także (3) tego, na ile ich zróżnicowanie wpłynie na podniesienie wartości naukowej i innowacyjność badań, a w konsekwencji także na bieg dalszej kariery naukowej i awansu zawodowego osób legitymujących się stopniem doktora. Nie mniej ważna jest odpowiedź na pytanie o (4) model studiów doktoranckich i uzasadnienie proponowanych zmian.

2. Autorzy projektów założeń zdecydowanie opowiadają się za zachowaniem stopnia doktora. Zarazem zgodnie dostrzegają potrzebę zmiany dotychczasowej filozofii odnoszącej się do procedury prowadzącej do jego nabycia. Przeświadczenie to budują na postępującej deprecjacji wartości naukowej doktoratów ${ }^{10}$ i stopniowo prawem obniżanych warunków stawianych jednostkom ubiegającym się o uprawnienie do nadawania stopnia naukowego doktora oraz kandydatom aspirującym do tego stopnia. Pogłębiającą się inflację doktoratów dostrzegają również $\mathrm{w}$ niestabilności prawodawcy ostatnich lat $\mathrm{w}$ dookreślaniu modelu studiów trzeciego stopnia (doktoranckich), w ich umasowieniu $^{11}$ i słabym umiędzynarodowieniu. Nie proponują zmian w tym zakresie (i słusznie) w oderwaniu od innych rekomendowanych rozwiązań dotyczących nowego ukształtowania pozycji uczelni w przestrzeni

VIS CONSUETUDINIS. Reforma nauki i akademii w Ustawie 2.0. Projekt założeń do ustawy Prawo o szkolnictwie wyższym, pod red. A. Radwana, Oficyna Allerhanda, Kraków 2017, dalej „Projekt trzeci” lub „zespół trzeci”.

${ }^{9}$ Ustawa z dnia 21 IV 2017 r. o zmianie ustawy o stopniach naukowych i tytule naukowym oraz o stopniach i tytule $\mathrm{w}$ zakresie sztuki oraz niektórych innych ustaw (Dz.U. poz. 859). Ustawa ta weszła w życie z dniem 29 IV 2017 r.

${ }^{10}$ Projekt pierwszy, s. 100; Projekt drugi, s. 156, 159; Projekt trzeci, s. 120.

${ }^{11}$ Ze szczególnym podkreśleniem nadreprezentacji uczestników studiów doktoranckich w obszarze nauk humanistycznych i społecznych, Projekt pierwszy, s. 100; Projekt drugi, s. 39; Projekt trzeci, s. 100-101. 
szkolnictwa wyższego i ich misji oraz kategorii, warunków prowadzenia przewodów doktorskich, a także wypracowania nowej formuły studiów doktoranckich i roli przez nie pełnionej dla nauki i otoczenia społeczno-gospodarczego.

Oceny i postulowane propozycje rozwiązań sprowadzają się głównie do dwóch, zespolonych ze sobą zagadnień: (1) możliwego wyboru dróg prowadzących do nabycia stopnia doktora oraz (2) przewodów doktorskich. W obrębie każdego z nich stanowiska autorów wprawdzie są ogólnie wyznaczonymi celami do siebie zbliżone, dla ich osiągnięcia zwykle jednak przyjmują alternatywne propozycje rozwiązań. $W$ ten sposób tworzą dobra, niekiedy i trudna, podstawę wyboru rozwiązań najlepiej służących kolejnej zmianie. W zakresie obu zagadnień proponowane rozwiązania dotyczą spraw unormowanych dwiema ustawami: ustawą o stopniach naukowych i tytule naukowym oraz o stopniach i tytule w zakresie sztuki z 2003 r. ${ }^{12}$ oraz ustawą Prawo o szkolnictwie wyższym z roku $2005^{13}$. Uchwalenie w styczniu 2017 r. ustawy nowelizującej ustawę z 2003 r. w zakresie nabywania stopnia doktora skłania do zastanowienia, $w$ jakim stopniu i które ze zmian proponowanych projektami założeń zostały ustawą tą już objęte oraz czy jej rozwiązania uwzględniają zapowiadane zmiany Prawa szkolnictwa wyższego.

Z uwzględnieniem obu źródeł (projektów założeń oraz znowelizowanej w 2017 r. ustawy) odpowiedzi wymagają pytania: (1) które z podmiotów nabędą lub zachowają uprawnienia do nadawania stopnia doktora; (2) kto będzie mógł wnioskować o wszczęcie przewodu doktorskiego; (3) w jakim zakresie ulec moga zmianie warunki przebiegu przewodów doktorskich; (4) w jakim kształcie i formule organizacyjnej powinno przebiegać kształcenie na studiach trzeciego stopnia.

\section{Według obowiązującego stanu prawnego uprawnienie do nada-} wania stopnia naukowego doktora może otrzymać jednostka organizacyjna ${ }^{14}$, która łącznie spełnia następujące warunki: (1) zatrudnia

${ }^{12}$ Ustawa z dnia 14 III 2003 r. o stopniach naukowych i tytule naukowym oraz o stopniach i tytułach naukowych w zakresie sztuki (tekst jedn. Dz.U. 2016, poz. 882).

${ }^{13}$ Ustawa z dnia 27 VII 2005 r. Prawo o szkolnictwie wyższym, w brzmieniu nadanym ostatnią nowelizacją tej ustawy, tj. Ustawą z dnia 23 VI 2016 r. o zmianie ustawy - Prawo o szkolnictwie wyższym oraz niektórych innych ustaw (Dz.U. poz. 1311). Tekst jedn. Dz.U. 2016, poz. 1842.

${ }^{14}$ Zgodnie z art. 4 pkt 3 ustawy z 2003 r. - w brzmieniu nadanym mu tekstem jednolitym tej ustawy w 2016 r. - jednostka organizacyjna oznacza wydział, inną jednostkę organizacyjną szkoły wyższej, instytut naukowy Polskiej Akademii Nauk, instytut 
w pełnym wymiarze czasu pracy co najmniej osiem osób z tytułem profesora lub stopniem doktora habilitowanego (lub z uprawnieniami równoważnymi z uprawnieniami doktora habilitowanego ${ }^{15}$ ), dla których jednostka ta jest podstawowym miejscem pracy (nie krócej niż jeden rok), reprezentujących dziedzinę nauki lub dziedzinę sztuki, w zakresie której jednostka ta ma otrzymać uprawnienie, z tym że pracowników $z$ tytułem naukowym lub stopniem doktora habilitowanego (lub osób, które nabyły uprawnienia równoważne $\mathrm{z}$ uprawnieniami doktora habilitowanego) reprezentujących dyscypliny naukowe w zakresie objętym uprawnieniem nie może być mniej niż pięciu; (2) uzyskała pozytywną ocenę poziomu działalności naukowej wydaną przez Centralną Komisję do Spraw Stopni i Tytułów (CK) na wniosek organu właściwego do podejmowania decyzji o nadaniu uprawnienia (art. 6 ust. 1, 3 i 4 ustawy) ${ }^{16}$.

Przepis ten uprawnienie do nadawania stopnia doktora przypisuje zatem jednostkom organizacyjnym nie tylko szkół wyższych oraz kształtuje wymagania dotyczące tzw. minimum kadrowego jednostki ( w dziedzinie nauki oraz dyscyplinie naukowej odpowiadającej zakresowi rozprawy doktorskiej ${ }^{17}$ ) i na nich opiera podstawę rozstrzygnięcia przez CK w sprawie przyznania lub odmowy przyznania uprawnienia do nadawania stopni naukowych.

W ocenie autorów założeń przepis ten wymaga zmiany. Po pierwsze dlatego, że kreuje zbyt niskie wymagania w zakresie minimum kadrowego przez to, że opiera je przede wszystkim na liczbie zatrudnionych pracowników (z tytułem naukowym profesora oraz stopniem naukowym doktora habilitowanego), i to niewielkiej, po drugie, opiera się

badawczy albo międzynarodowy instytut naukowy utworzony na podstawie odrębnych przepisów, działający na terytorium Rzeczypospolitej Polskiej.

${ }^{15}$ Chodzi tu o osoby, które uzyskały stopień doktora w Rzeczypospolitej Polskiej lub za granicą i podczas pracy w innym państwie przez co najmniej pięć lat kierowały samodzielnie zespołami badawczymi oraz posiadają znaczący dorobek i osiągnięcia naukowe, zatrudnione są na stanowisku profesora nadzwyczajnego lub profesora wizytującego i na podstawie decyzji uzyskały uprawnienie równoważne z posiadaniem stopnia doktora habilitowanego (art. 21a ustawy o stopniach naukowych i tytule naukowym oraz o stopniach i tytule w zakresie sztuki).

${ }^{16}$ Art. 5 ust. 2, art. 6 ust. 1, 3 i 4 ustawy z 2003 r. w brzmieniu nadanym Obwieszczeniem Marszałka Sejmu Rzeczypospolitej Polskiej z dnia 3 VI 2016 r. w sprawie ogłoszenia jednolitego tekstu ustawy o stopniach naukowych i tytule naukowym oraz o stopniach i tytule w zakresie sztuki (Dz.U. poz. 882). Postanowień w tym zakresie nie zmieniła ustawa zmieniająca z $2017 \mathrm{r}$.

${ }^{17}$ Zgodnie z art. 14a ust. 1 i 7 obowiązującej ustawy z 2003 r. stopień doktora jest nadawany w dyscyplinie naukowej. 
wyłącznie na ocenie statystycznie (ogólnie) ujętych efektów działalności naukowej jednostki organizacyjnej w oderwaniu od jakości prowadzonych w niej badań naukowych (promocja ilości nad jakością) ${ }^{18}$, po trzecie, nadanie stopnia doktora sprowadza do określonej dyscypliny naukowej. Zakres podnoszonych zmian ustawowej regulacji uzupełniają nadto o kolejne propozycje rozwiązań. W efekcie proponują nowe wymagania stawiane przed uczelniami i jednostkami naukowymi w zakresie nabycia i posiadania uprawnienia do nadawania stopnia doktora. W odniesieniu do szkół wyższych podstawowe założenia sprowadzają do dwóch wytycznych: (1) przyznawania prawa do nadawania stopni naukowych (całym) uczelniom, (2) w dziedzinach nauki mocnych kadrowo i aktywnych badawczo.

W kwestii pierwszej oznacza to propozycję odstąpienia od dotychczasowego unormowania rezerwującego dla jednostek organizacyjnych uczelni (spełniających prawem stawiane wymagania) uprawnienia do nadawania stopni naukowych, w kwestii drugiej natomiast oparcia rozwiązań na założeniu, zgodnie z którym stopnie naukowe mają być nadawane $\mathrm{w}$ danej dziedzinie wiedzy. Tę propozycję zmiany autorzy założeń wzmacniają docelowo wymogiem przeformułowania jednostek organizacyjnych uczelni tak, by odpowiadały one odpowiednim dziedzinom nauki ${ }^{19}$. I choć jest to rewolucyjna propozycja zmiany ${ }^{20}$, optują

${ }^{18} \mathrm{~W}$ ocenie zespołu drugiego „[k]onieczne jest zaostrzenie kryteriów koniecznych do uzyskania praw do nadawania stopni naukowych i uzależnienie ich od jakości prowadzonych badań poprzez powiązanie ich z oceną parametryczną", Projekt drugi, s. 161-162. Podobnie zespół pierwszy: „[...] warunkiem przyznania uprawnień powinna być nie, jak obecnie, ogólna ocena "poziomu działalności naukowej lub artystycznej jednostki», lecz spełnienie przez szkołę wyższą wymogu posiadania w danym zakresie (dyscyplinie) kategorii naukowej «A+» lub «A»", Projekt pierwszy, s. 55.

${ }^{19} \mathrm{~W}$ ocenie zespołu trzeciego "[d] ocelowo pożądana jest jednak taka struktura uczelni, w której podział na jednostki podstawowe (wydziały, szkoły) pokrywa się z podziałem na dziedziny wiedzy", Projekt trzeci, s. 119.

${ }^{20}$ Aktualnie obowiązujące Rozporządzenie Ministra Nauki i Szkolnictwa Wyższego z dnia 8 VIII 2011 r. w sprawie obszarów wiedzy, dziedzin nauki i sztuki oraz dyscyplin naukowych i artystycznych (Dz.U. Nr 179, poz. 1065) przyjmuje trójstopniowy podział nauk, przewiduje osiem obszarów wiedzy, dwadzieścia dwie dziedziny nauk oraz dziewięćdziesiąt pięć dyscyplin naukowych. Należałoby jednak rozważyć przyjęcie dwustopniowej klasyfikacji nauk, za czym optują także autorzy założeń, z zastrzeżeniem jednakże oparcia jej na systematyce przyjętej przez Organizację Współpracy Gospodarczej i Rozwoju (OECD), obejmującej sześć dziedzin nauki (nauki przyrodnicze, nauki inżynieryjne i techniczne, nauki medyczne i nauki o zdrowiu, nauki rolnicze, nauki społeczne, nauki humanistyczne oraz sztuka), Klasyfikacja dziedzin nauki i techniki według OECD, http://www.ncbr.gov.pl/gfx/ncbir/userfiles/_public/fundusze_europejskie/ 
za nią autorzy wszystkich trzech projektów założeńen ${ }^{21}$. Nie czynią tego jednak bez zastrzeżeń. Zespoły pierwszy i drugi proponują wariantowe rozwiązania - nadawanie stopni naukowych w zakresie dyscyplin naukowych skomasowanych z dziedzinami nauki (zespół pierwszy), przyjęcie za najszersze - dyscypliny naukowe, za węższe - zakresy dziedzin nauki, za najwęższe - wąskie specjalizacje (zespół drugi). Wariantowo proponowane rozwiązania bez wątpienia nie zaburzą zbytnio istniejącej już struktury organizacyjnej jednostek uczelni i w tym zakresie jest to rozwiązanie lepsze. Można także założyć, że odpowiednio skonfigurowane dyscypliny naukowe lepiej służyć będą zdefiniowaniu stopnia doktora i uprawnieniom jednostek organizacyjnych uczelni w przeprowadzaniu przewodów doktorskich.

Tej logice powinny być też podporządkowane warunki determinujące prawo uczelni do nadawania stopnia doktora. Powinny je wyznaczać dwie determinanty: parametryczna ocena działalności naukowej uczelni oraz warunki potrzebne do ustalenia tzw. minimum kadrowego.

$\mathrm{W}$ kwestii pierwszej - $\mathrm{w}$ dotychczasowych rozwiązaniach parametrycznej ocenie mogły poddać się jednostki organizacyjne (wydziały) uczelni, a uzyskana przez nie kategoria (od 2015 r. mająca wpływ na dofinansowanie danej jednostki organizacyjnej) nie miała znaczenia dla oceny w przedmiocie nabycia lub utraty uprawnienia do nadawania stopni naukowych. Rozwiązania przyjęte założeniami idą w innym kierunku: ściślejszego powiązania uprawnienia uczelni do nadawania stopni naukowych z systemem parametrycznej oceny jej działalności naukowej w dziedzinach wiedzy (bądź skomasowanych dyscyplinach naukowych) i z uzyskaną w jej efekcie kategorią naukową.

$\mathrm{W}$ proponowanych rozwiązaniach uprawnienie do nadawania stopnia doktora ma więc służyć uczelniom, a nie jej jednostkom organizacyjnym ${ }^{22}$. Przy tym prawo $\mathrm{w}$ tym zakresie będą mogły nabyć jedynie niektóre uczelnie (spośród trzech zaproponowanych grup: badawcze, badawczo-dydaktyczne, dydaktyczne), a mianowicie wyłącznie dwie pierwsze (badawcze i badawczo-dydaktyczne), tj. te, które

inteligentny_rozwoj/1_4_1_4_2015/2_wykaz_dziedzin_nauki_i_technik_wedlug_klasyfikacji_oecd.pdf (dostęp: 21 VII 2017).

${ }^{21}$ Projekt pierwszy, s. 55; Projekt drugi, s. 27; Projekt trzeci, s. 118-119.

${ }^{22} \mathrm{~W}$ ocenie zespołu pierwszego „podmiotami mogącymi mieć uprawnienia w zakresie nadawania stopni naukowych, jak również mającymi status jednostek badawczych w systemie szkolnictwa wyższego powinny być jedynie szkoły wyższe w całości, bez względu na to, czy ich statuty przewidują występowanie podstawowych jednostek organizacyjnych, Projekt pierwszy, s. 54; podobnie Projekt drugi, s. 27, 49, 162. 
w parametrycznej ocenie działalności naukowej uzyskają (według proponowanych założeń) kategorię B-1 lub wyższą $(\mathrm{A}+, \mathrm{A})^{23}$. Zarazem autorzy założeń nie negują zachowania realizacji uprawnienia w tym zakresie przez jednostki organizacyjne (wydziały), wszakże tylko te wskazane we wniosku uczelni o jego uzyskanie, a w razie jego posiadania - w akcie organu szkoły wyższej wskazanym w tym celu w statucie ${ }^{24}$. Proponują zatem zbudowanie kategorii naukowej uczelni opartej na parametrze osiągnięć naukowych $\mathrm{w}$ danej dziedzinie wiedzy jednostek organizacyjnych wchodzących w jej skład i przez nią we wniosku wskazanych ${ }^{25}$. I jest to dobra propozycja zmiany ${ }^{26}$, pod warunkiem jasno wyznaczonych kryteriów mierzenia osiągnięć naukowych również parametrem jakościowym. Zaletą tego rozwiązania jest bez wątpienia budowanie prestiżu naukowego uczelni, a nie wyłącznie jednostek organizacyjnych stanowiących części większej całości, przy jednoczesnym uwzględnieniu kryteriów oceny dostosowanych do rzeczywiście istniejących praktyk naukowych i publikacyjnych wyznaczających do-

${ }^{23}$ Zgodnie $\mathrm{z}$ aktualnym stanem prawnym są cztery kategorie naukowe: $\mathrm{A}+, \mathrm{A}$, B i C. Jednostka naukowa może otrzymać tylko jedną z trzech kategorii (A, B lub C), dodatkowo w ocenie eksperckiej Komitet Ewaluacji Jednostek Naukowych (KEJN) może rekomendować przyznanie danej jednostce kategorii $\mathrm{A}+\mathrm{W}$ opinii zespołu drugiego kategoria B jest zbyt pojemna i zbyt niejednolita, stąd propozycja wyodrębnienia dwóch subkategorii: B-1 będącej „przedpolem” do kategorii A oraz B-2. Uprawnienie do nadawania stopnia doktora będą mogły uzyskać szkoły wyższe z kategorią co najmniej B-1, Projekt drugi, s. 26-27, 49, 162. Na sposób budowania typów uczelni oparty na kategorii naukowej jednostek organizacyjnych wskazują także autorzy zespołu pierwszego. Zespół ten sytuuje najwyżej uczelnie badawcze, które powinny „mieć co najmniej 1/10 najwyższych kategorii naukowych $(\mathrm{A}+)$ w stosunku do uzyskanych kategorii naukowych i łącznie ponad połowę kategorii A+ i A - oraz nie mieć kategorii najniższej (C)", a ponadto uczelnie badawczo-dydaktyczne, tj. takie, w których udział uzyskanych wyższych kategorii naukowych (A+i A) wynosiłby co najmniej 1/3 całości uzyskanych kategorii, przy założeniu, że nie byłoby kategorii C. Tylko dwie pierwsze grupy uczelni, z wyłączeniem więc uczelni dydaktycznych (zawodowych), będą miały uprawnienia do nadawania stopni naukowych, Projekt pierwszy, s. 41-43. Zespół trzeci postuluje udoskonalenie systemu ewaluacji bazującej na parametryzacji przez wdrożenie wielowymiarowej oceny jednostek naukowych ex ante, Projekt trzeci, s. 202-204.

${ }^{24}$ Projekt pierwszy, s. 54.

${ }^{25}$ Projekt trzeci, s. 229.

${ }^{26} \mathrm{~W}$ opinii zespołu drugiego „[o]znacza to odejście od prowadzenia oceny parametrycznej w oparciu o wydziały uczelni i ewolucję w stronę ewaluacji badań prowadzoną w ramach dziedzin nauki niezależnie od rozwiązań organizacyjnych przyjętych w poszczególnych uczelniach (w kolejnym cyklu parametryzacji)", Projekt drugi, s. 27; podobnie Projekt trzeci, s. 119: „Kategoryzacja jest dokonywana dla poszczególnych dziedzin, a nie dla podstawowych jednostek wewnętrznych uczelni (wydziały)". 
skonałość naukową ${ }^{27}$ wydziałów ważną w zakresie realizacji uprawnienia uczelni do nadawania stopnia doktora. Przy takim założeniu $\mathrm{w}$ praktyce realizacja tego zamierzenia nie powinna budzić sporów, a w każdym razie nie może przysparzać kłopotów w ocenie kategorii naukowej danej szkoły wyższej, opartej na osiągnięciach naukowych tworzących ją jednostek organizacyjnych ${ }^{28}$. Cały ciężar powinien jednak spoczywać na uczelni i jej swobodzie w wyborze wydziału wskazanego we wniosku o nabycie (bądź zachowanie) uprawnienia do doktoryzowania. Zaburzenie tego założenia w świetle obowiązujących przepisów ${ }^{29}$ nie jest możliwe. Prawo nie wiąże bowiem jednostek organizacyjnych obowiązkiem poddania się parametrycznej ocenie działalności naukowej. Jednakże $z$ rezygnacją z poddania się tej ocenie wiążą się i słabe strony. Po pierwsze, niemożliwość uzyskania dotacji statutowej przydzielanej przez ministra nauki i szkolnictwa wyższego, po drugie, brak uprawnienia do nadawania stopni naukowych.

Można założyć, że duże uczelnie, o rozbudowanej strukturze wydziałowej, posiadające uprawnienia do nadawania stopni naukowych będą zainteresowane poddaniem się w każdym cyklu (cztero- bądź

${ }^{27}$ Projekt drugi, s. 163. Sprowadzenie tego parametru przede wszystkim do publikacji naukowych w zagranicznych czasopismach, w szczególności tych z wyliczonym wskaźnikiem IF (przez stworzenie zachęt do publikowania na ich łamach), co podnosi zespół drugi, nie jest, a w każdym razie być nie powinno, miernikiem jedynie słusznym, Projekt drugi, s. 40-41. Na ostrożną ocenę w tym zakresie słusznie uwagę zwraca zespół trzeci. Publikowane artykuły naukowe (w lawinowo rosnącej liczbie) w czasopismach „z trzeciej i czwartej ćwiartki rozkładu punktowego (malejąco)" nie pozwalają na ustalenie ich wartości naukowej, "gdyż cytowanie samych publikacji nie jest przedmiotem oceny. Na pewno natomiast przyczyniają się do rozwoju zagranicznych czasopism naukowych", i to tych pobierających "szereg opłat związanych z przyjęciem artykułu oraz jego publikacją", Projekt trzeci, s. 204. Nie stoi temu na przeszkodzie, słuszna skądinąd, propozycja zespołu drugiego wprowadzenia polskich czasopism naukowych do najbardziej prestiżowych baz indeksacyjnych typu Web of Science Core Collection i SCOPUS przy szerokim wsparciu tego procesu ze środków publicznych. Natomiast zdecydowanie trudno podzielić pogląd zespołu drugiego w sprawie zmiany formuły listy B czasopism naukowych ustalonej przez ministra nauki i szkolnictwa wyższego "poprzez nadanie indeksowanym w niej tytułom jednakowo niskiej (ryczałtowej) wartości punktowej", Projekt drugi, s. 40-41.

${ }^{28} \mathrm{Z}$ zastrzeżeniem rzetelnie sporządzonego wniosku i jego udokumentowania. $\mathrm{W}$ przeciwnym razie uczelnia utraci uprawnienie do nadawania stopnia doktora mimo posiadanej kategorii A, A+ lub B-1 w danej dziedzinie wiedzy, mocą decyzji CK, Projekt drugi, s. 93-94.

${ }^{29}$ Rozporządzenie Ministra Nauki i Szkolnictwa Wyższego z dnia 12 XII 2016 r. w sprawie przyznawania kategorii naukowej jednostkom naukowym i uczelniom, w których zgodnie $\mathrm{z}$ ich statutami nie wyodrębniono podstawowych jednostek organizacyjnych (Dz.U. poz. 2154). 
pięcioletnim) parametrycznej ocenie działalności naukowej, z obu powyżej wskazanych powodów (dotacji statutowej oraz nabycia lub zachowania nabytych już uprawnień do nadawania stopni naukowych). Z wynikami tej oceny sprzężona jest jednak kategoria naukowa jednostek organizacyjnych. Uzyskanie kategorii $C$ choćby przez jedną jednostkę organizacyjną uczelni wykluczy ją z grona uczelni badawczych i badawczo-dydaktycznych, a tym samym z możliwości nabycia (lub zachowania) uprawnienia do nadawania stopni naukowych, w tym stopnia doktora. Stawia to uczelnie przed dojrzałymi, wstępnie autonomicznie zweryfikowanymi, wyborami swoich jednostek organizacyjnych, podjętymi przed ich zgłoszeniem we wniosku o nabycie (bądź zachowanie) uprawnienia do nadawania stopni naukowych. Przyjęcie stanowiska odmiennego - wyznaczenie statusu uczelni na podstawie sumy parametrycznej oceny działalności naukowej każdej z jej jednostek organizacyjnych ( $w$ tym tych z potencjalną kategorią $C^{30}$ ) - nieuchronnie prowadziłoby do zminimalizowania liczby uczelni badawczych i badawczo-dydaktycznych, a w konsekwencji do stworzenia zapowiadanej, i postulowanej w projektach założeń, wąskiej liczby uczelni "flagowych", wysoko dotowanych. Przeciwwagę dla tego typu rozwiązania powinna stanowić nie tylko transparentność przepisów prawnych w zakresie wyłaniania grup uczelni, ale także określenie ex ante, nie zaś ex post warunków ewaluacji opartej na parametrycznej ocenie działalności naukowej ${ }^{31}$.

Parametryzacji według zasad przyjętych dla szkół wyższych nie powinny być poddawane instytuty naukowe PAN i instytuty badawcze. I w tej sprawie autorzy projektów są zgodni ${ }^{32}$, co nie oznacza propozycji wyłączenia tej grupy jednostek z prawa do nadawania stopnia doktora. Zespół drugi proponuje nadto w ogóle wyłączenie spod oceny parametrycznej małych jednostek organizacyjnych niebędących jednostkami uczelnianymi ${ }^{33}$. I choć nie przybliża tej propozycji, jest to trafna uwaga. Z pewnością z tego punktu widzenia (parametryzacji i jej wyniku

\footnotetext{
${ }^{30}$ Kategoria C jednostki organizacyjnej wyklucza ją z prawa nadawania stopnia doktora.

${ }^{31}$ Znaczenie tego warunku wyraźnie podkreślają autorzy projektów założeń zespołu trzeciego, Projekt trzeci, s. 203-204.

32 Projekt pierwszy, s. 54, 71, 89. W ocenie zespołu drugiego z oceny parametrycznej powinny "być wyłączone instytuty badawcze i instytuty PAN (które będą parametryzowane według osobnych reguł)", Projekt drugi, s. 26.

${ }^{33}$ Projekt drugi, s. 26.
} 
potwierdzonego uzyskaną kategorią) zbyt duża (rozproszona) liczba jednostek organizacyjnych uczelni w zakładanym projekcie wzmacniać jej nie będzie.

W kwestii drugiej - odnoszonej do minimum kadrowego wymaganego do uzyskania i posiadania uprawnienia do nadawania stopnia doktora - stanowisko autorów założeń także nie jest jednoznaczne. Wprawdzie prawo tworzenia minimów (zgodnie $\mathrm{z}$ ustawowymi ustaleniami) zachowują dla wydziałów, zdecydowanie wszakże opowiadają się za ich zaostrzeniem ${ }^{34}$. Jednocześnie wyzwanie to warunkują rozstrzygnięciami przyszłego ustawodawcy w zakresie przyjęcia lub odrzucenia proponowanej nowej kategorii naukowej szkół wyższych i podstaw ich klasyfikacji (wyróżnienia). Toteż zespoły pierwszy i drugi zastrzegają podwyższenie minimum kadrowego $w$ razie pozostawienia na dotychczasowym poziomie parametrycznej oceny działalności naukowej wydziału/uczelni, przy czym jedynie zespół drugi formułuje wyraźną w tym zakresie propozycję: podwyższenie minimum kadrowego z ośmiu do co najmniej dwunastu osób z tytułem naukowym profesora lub stopniem naukowym doktora habilitowanego, w tym trzech profesorów oraz ośmiu doktorów habilitowanych - wszyscy z danej dziedziny nauki ${ }^{35}$. Zgodnie też (i trafnie) autorzy pierwszego i drugiego zespołu przyjmują wyłączenie z minimum kadrowego osób z uprawnieniami równoważnymi z uprawnieniem doktora habilitowanego na podstawie art. 21a (art. 6 ust. 3 ustawy z 2016 r.) ${ }^{36}$. Z kolei zespół trzeci poszedł $\mathrm{w}$ innym kierunku. Uprawnienie do nadawania stopnia doktora postuluje wiązać jedynie $\mathrm{z}$ siłą naukową uczelni $\mathrm{w}$ danej dziedzinie nauki (najmniej z kategorią B), nie z minimum kadrowym ${ }^{37}$.

Tym samym założenia w zakresie uzyskania i posiadania uprawnienia do nadawania stopnia doktora proponują ( $\mathrm{z}$ wyłączeniem zespołu trzeciego) uwzględnienie dwóch elementów oceny: kategorii naukowej (mierzonej parametryczną oceną faktycznie osiągniętych i wartościowych efektów działalności naukowej) oraz potencjału naukowego

\footnotetext{
${ }^{34} \mathrm{~W}$ ocenie zespołu pierwszego „[m] $[\mathrm{minima}$ kadrowe wymagane do uzyskania i posiadania uprawnień do nadawania stopnia doktora - powinny być znacznie podwyższone [...] wyższe niż przyjęte obecnie dla habilitacji [...] z zastrzeżeniem, że określenie wymaganej liczby osób wchodzących w skład «minimum» zależy od uprzedniego rozstrzygnięcia w przedmiocie podziału na obszary, dziedziny i dyscypliny naukowe [...]", Projekt pierwszy, s. 54-55.

${ }^{35}$ Projekt drugi, s. 162.

${ }^{36}$ Projekt pierwszy, s. 55; Projekt drugi, s. 163.

${ }^{37}$ Projekt trzeci, s. 123.
} 
wydziału/uczelni (mierzonego jej składem osobowym). Nie różnicują przy tym tych wymagań ze względu na typy doktoratów (naukowe i zawodowe). Nie czyni tego także ustawa z 2017 r. W kwestii natomiast, czy opierając się na ocenach tych wartości, Centralna Komisja ma weryfikować uprawnienie uczelni do nadawania stopnia doktora (na jej wniosek), zdania autorów projektów założeń są już podzielone. Zespoły pierwszy i drugi optują za zachowaniem CK i powierzeniem jej zwiększonej roli w nadzorowaniu postępowań w jednostkach organizacyjnych z jednoczesnym zwiększeniem transparentności jej działania i profesjonalizacji ${ }^{38}$. Przy czym zespół pierwszy ponad tę uwage wychodzi i proponuje połączenie CK z KEJN. W przeciwnym razie (tj. odrzucenia tej propozycji) rekomenduje pozostawienie CK działającej po zasięgnięciu opinii Rady Głównej Nauki i Szkolnictwa Wyższego ${ }^{39}$. Odmienne stanowisko zajmują autorzy zespołu trzeciego, proponujący odstapienie od instytucji Centralnej Komisji ${ }^{40}$.

4. Zgodnie $z$ prawem dawniej i obecnie obowiązującym drogę prowadzącą do nabycia stopnia doktora wyznaczały i wyznaczają różne „ścieżki": asystentura, studia doktoranckie, doktorat z tzw. wolnej stopy. Autorzy projektów w tym zakresie nie proponują (i słusznie) większych zmian. Ich ogląd każdej z tych dróg jest zabarwiony różnymi wartościami. W ocenie zespołu pierwszego asystentura, wyparta przez studia doktoranckie, jest obecna w niewielu już uczelniach ${ }^{41}$. I w istocie tak jest. Nie dlatego, że formuła studiów doktoranckich jest lepszym wyborem, lecz dlatego, że (1) nie każda z jednostek organizacyjnych uczelni spełnia warunki do nabycia uprawnienia do nadawania stopnia doktora, w tym swoim asystentom (co w obecnym stanie prawnym nie wyklucza wszczęcia przewodu doktorskiego w innej uczelni mającej uprawnienie $\mathrm{w}$ tym zakresie na podstawie porozumienia zawartego z uczelnią takiego uprawnienia niemającej), bądź też że (2) asystenturę zachowały niezależnie od prowadzonych studiów doktoranckich. W obu sytuacjach dla osoby zainteresowanej wszczęciem przewodu

${ }^{38} \mathrm{~W}$ ocenie zespołu drugiego działanie CK powinno nadto podlegać, na wniosek ministra nauki i szkolnictwa wyższego, cyklicznej ewaluacji prowadzonej przez międzynarodowy zespół ekspertów. Zmiany wymaga także system wyboru członków CK, na wzór podobny do wyboru członków rady Narodowego Centrum Nauki, Projekt drugi s. $34,49,154,163$.

${ }^{39}$ Projekt pierwszy, s. 48, 55-56.

${ }^{40}$ Projekt trzeci, s. 117

${ }^{41}$ Projekt pierwszy, s. 90. 
doktorskiego (na dotychczasowych zasadach) nie ma to większego znaczenia. Dla uczelni zatrudniających na stanowisku asystenta sprawa ta może wyglądać zgoła odmiennie. Nie może tu bowiem z pola widzenia uciec paralela odnoszona do stosunku: liczba nauczycieli akademickich uczelni (N) a suma ich osiągnięć naukowych, w efekcie determinująca, $\mathrm{w}$ wyniku parametrycznej oceny działalności naukowej danej szkoły wyższej (dotąd jednostek organizacyjnych), jej kategorię naukową, ale i (3) możliwość dotowania uczelni prowadzącej studia doktoranckie. Oczywiście, dylematu tego rodzaju zdecydowanie nie powoduje możliwość doktoryzowania z tzw. wolnej stopy. Wprawdzie droga prowadząca do uzyskania stopnia doktora bez limitu dysertacji może być nakierowana na pozyskiwanie przez uczelnie i jej jednostki organizacyjne środków finansowych w wysokości autonomicznie przez nie ustalanej, autorzy trzech projektów założeń tego zagadnienia jednak wprost nie podnosza, zgodni są natomiast co do tego, by liczba wszczynanych w tej ścieżce przewodów doktorskich stanowiła niewielki jedynie ułamek ${ }^{42}$.

Bez względu na obraną drogę prowadzącą do nabycia stopnia doktora obowiązujące w $2016 \mathrm{r}$. rozwiązania prawne nie prowadzą do różnicowania stopnia doktora na stopień naukowy i zawodowy. Nie czyniły tego także rozwiązania przyjęte w latach 1951-1958, mimo wprowadzenia (oprócz asystentury) na wzór radziecki aspirantury naukowej oraz odrębnie uregulowanej aspirantury naukowej dla osób pracujących zawodowo, uzasadnionej potrzebami współpracy nauki z otoczeniem społeczno-gospodarczym ${ }^{43}, \mathrm{w}$ obu przypadkach prowadzącej do uzyskania niższego stopnia naukowego - kandydata nauk ${ }^{44}$. Projekty założeń wprawdzie do rozwiązań z tamtych lat wprost się nie odwołuja, co do istoty jednak są ich powieleniem, z uwzględnieniem wszakże zmian dopuszczalnych prawem i warunkami finansowymi współczesnego państwa. Podobnie jak w latach pięćdziesiątych minionego stulecia proponują w odniesieniu do zawodowych doktoratów wdrożeniowych dualność w ich prowadzeniu (szkoła wyższa - podmiot

${ }^{42}$ Projekt trzeci, s. 133.

${ }^{43}$ Szerzej na ten temat zob. K. Wojtczak, O stopniach naukowych w Polsce Ludowej. Czesść 2. Organizacja aspirantury naukowej i studiów doktoranckich , Studia Prawa Publicznego" 2016, nr 2(14), s. 49-64.

${ }^{44} \mathrm{~K}$. Wojtczak, O stopniach naukowych w Polsce Ludowej. Część 1. Niższe stopnie naukowe, „Studia Prawa Publicznego" 2016, nr 1(13), s. 27-46 (w odniesieniu do stopnia naukowego kandydata nauk), oraz s. 46-65 (w odniesieniu do stopnia naukowego doktora). 
zatrudniający doktoranta spoza uczelni), w odróżnieniu od tamtych rozwiązań opowiadają się jednak za dwumianowością doktoratu: naukowy (akademicki) oraz typu zawodowego (wdrożeniowy) ${ }^{45}$.

Nowelizacja ustawy z 2003 r. o stopniach naukowych z roku 2017 w duchu tych rozwiązań nie podąża. Przeciwnie, przewiduje nadawanie stopnia doktora bez względu na to, czy rozprawę doktorską stanowi oryginalne rozwiązanie problemu naukowego czy praca projektowa, konstrukcyjna, technologiczna bądź wdrożeniowa lub artystyczna, o ile stanowi ona oryginalne rozwiązanie problemu (oparte na tych pracach) oraz wykazuje ogólną wiedzę teoretyczną kandydata w danej dyscyplinie naukowej (lub artystycznej) i umiejętność samodzielnego prowadzenia pracy naukowej lub artystycznej (art. 13 ust. 1 i 3 ustawy z 2017 r.). Z treści zmienionej w 2017 r. ustawy z roku 2003 wynika więc, że zasadność wprowadzenia, oprócz akademickiego stopnia naukowego doktora, doktoratu typu zawodowego jako trzeciego tytułu w ramach trójszczeblowego "systemu bolońskiego" (zaproponowanego przez autorów zespołu pierwszego jako wynik przewodu z "wolnej stopy”) jest dość kontrowersyjna. Nie dlatego, że osoba pracująca nad przygotowaniem doktoratu zawodowego poza uczelnia, czyli "z wolnej stopy” ( $\mathrm{z}$ wyłączeniem doktoratu wdrożeniowego, co wynika wprost z ustawy z 2017 r.), jest poddana ocenie jedynie swego opiekuna naukowego w uczelni (seminaria), co może dotyczyć także doktoratu naukowego, lecz dlatego, że nie obowiązują jej warunki przyjęte dla uczestników studiów doktoranckich, chyba że uczelnie studia takie (o profilu zawodowym) wprowadzą. Tylko wtedy uczestnikami tych studiów (o profilu zawodowym) mogłyby zostać: (1) osoby przyjęte w drodze rekrutacji na te studia, ale też, przy uwzględnieniu zastrzeżenia zespołu pierwszego, (2) te będące uczestnikami studiów doktoranckich o profilu naukowym, co do których stwierdzono "W wyniku oceny dokonanej w połowie odbywania studiów doktoranckich o profilu naukowym brak perspektyw uzyskania oczekiwanego efektu" ${ }^{\prime \prime 6}$, jak i (3) te, które w ocenie pracy nad przygotowaniem rozprawy doktorskiej oraz perspektywą ukończenia studiów doktoranckich w terminie uzyskały ocenę dostateczną ${ }^{47}$. Oczywiście, można założyć, że odstąpienie od doktoratu naukowego

${ }^{45}$ Projekt pierwszy, s. 101. Tytułem zawodowym doktora zespół ten obejmuje także przewody doktorskie zakończone przedstawieniem innowacyjnej pracy projektowej, technologicznej lub artystycznej.

${ }^{46}$ Ibidem.

${ }^{47}$ Projekt pierwszy, s. 91. 
także przy zaistnieniu innych przesłanek będzie możliwe, tak jak możliwa być powinna również sytuacja odwrotna, przy wyraźnie jednak sformułowanych przez ustawodawcę (lub uczelnię) warunkach i zasadach, za zgodą właściwej rady. Szerszej oceny tej możliwej zmiany zabrakło jednak w projektach założeń. Wprawdzie propozycja zespołu pierwszego w nierównorzędnym traktowaniu doktoratów jest konsekwentna, co znajduje także odzwierciedlenie w proponowanej nazwie stopnia/ tytułu, np. "dr nauk prawnych" (doktorat o profilu naukowym) - "dr prawa w zakresie prawa karnego materialnego" (doktorat zawodowy) ${ }^{48}$, nie może ona jednak nie budzić wątpliwości ${ }^{49}$. Bezsprzecznie stawia wyraźną granicę między doktoratem naukowym a zawodowym. Różnicę tę wzmacnia ponadto propozycja zatwierdzania przez CK wyłącznie naukowego stopnia doktora.

Tę optykę różnicowania doktoratów nieco zmienia wprowadzenie ustawą z 2017 r. programu "Doktorat wdrożeniowy” oraz określenie w drodze rozporządzenia szczegółowych warunków jego realizacji ${ }^{50}$. Do jego wdrożenia i stosowania ustawa upoważnia uczelnie i jednostki naukowe ${ }^{51}$, i to tylko te, które: (1) posiadają najwyższą kategorię naukową A+ lub A (założenia dla doktoratów naukowych proponują także kategorię B-1, a zatem niższą); (2) prowadzą stacjonarne studia doktoranckie, przewidziane art. 195 ustawy Prawo o szkolnictwie wyższym, o koncepcji mającej, stosownie do realizacji programu, znaczenie praktyczne; (3) udokumentują systematyczną współpracę z przedsiębiorcami lub

${ }^{48}$ Projekt pierwszy, s. 102.

${ }^{49}$ Nawet przy założeniu, że „[w] obydwóch przypadkach zachowane byłyby tradycyjne zasady procedury doktorskiej - z tym że prace, których przedstawienie stanowiłoby podstawową przesłankę nadania odpowiednio tytułu zawodowego i stopnia doktora, można byłoby przygotować (i wdrożyć lub opublikować) także przed wszczęciem przewodu", Projekt pierwszy, s. 101-102.

${ }^{50}$ Rozporządzenie Ministra Nauki i Szkolnictwa Wyższego z dnia 10 II 2017 r. zmieniające rozporządzenie w sprawie szczegółowego trybu i warunków przeprowadzania czynności w przewodzie doktorskim, w postępowaniu habilitacyjnym oraz w postępowaniu o nadanie tytułu profesora (Dz.U. poz. 271).

${ }^{51}$ W tym zakresie ustawa z 2017 r. odsyła do Ustawy z dnia 30 IV 2010 r. o zasadach finansowania nauki (tekst jedn. Dz.U. 2016, poz. 2045 ze zm.). W odwołaniu do niej program "Doktorat wdrożeniowy” będą mogły poza jednostkami organizacyjnymi uczelni realizować: jednostki naukowe Polskiej Akademii Nauk (w rozumieniu Ustawy z dnia 30 IV 2010 r. o Polskiej Akademii Nauk - tekst jedn. Dz.U. 2016, poz. 572 ze zm.), instytuty badawcze (w rozumieniu Ustawy z dnia 30 IV 2010 r. o instytutach badawczych - tekst jedn. Dz.U. 2016, poz. 371 ze zm.) oraz międzynarodowe instytuty naukowe utworzone na podstawie odrębnych przepisów, działające na terytorium Rzeczypospolitej Polskiej mające kategorię naukową A+ lub A. 
innymi podmiotami w zakresie działalności badawczo-rozwojowej. To tym podmiotom ustawa daje prawo zgłoszenia do udziału w programie osób posiadających tytuł zawodowy magistra lub równorzędny, przyjętych na stacjonarne studia doktoranckie (a zatem nie $\mathrm{z}$ „wolnej stopy”), które sac lub zostaną zatrudnione w pełnym wymiarze czasu pracy przez przedsiębiorcę bądź inny podmiot wyrażający zgodę na jej udział w studiach doktoranckich $w$ ramach programu. Celem i istotą tego programu ma być tworzenie warunków do rozwoju i współpracy między środowiskiem naukowym a środowiskiem społeczno-gospodarczym. W tej dualnej realizacji programu i celu jego wdrożenia można dostrzec podobieństwo do rozwiązań wprowadzonej w latach minionych aspirantury naukowej dla osób pracujących zawodowo ${ }^{52}$. Podobnie jak w tamtych rozwiązaniach opiekę naukową nad doktorantem w ramach tego programu ma sprawować promotor ( $z$ danej uczelni, jednostki naukowej) oraz opiekun, tu opiekun pomocniczy (co jest nowym rozwiązaniem), którego kandydaturę wskazuje podmiot zatrudniający doktoranta spośród swoich pracowników, a wyznacza dziekan lub dyrektor jednostki naukowej prowadzącej studia doktoranckie w ramach programu. Czy są to doktoranckie studia zawodowe, o których mówią autorzy projektów założeń zespołu pierwszego, trudno przesądzać. Z pewnością natomiast ustawa z 2017 r. nie daje podstawy do przyjęcia stanowiska autorów tego zespołu w sprawie nadania obronionym rozprawom doktorskim tytułu zawodowego, a nie stopnia doktora. Tym samym trudno także obronić tezę tego zespołu o rezygnacji ze stopnia doktora dla obronionych rozpraw doktorskich stanowiących pracę projektowa, konstrukcyjną, technologiczną lub artystyczną.

\section{Zgodnie z prawem obowiązującym przewodem doktorskim obję-} to: (1) wszczęcie przez właściwą radę (wydziału, naukową) przewodu doktorskiego, (2) złożenie egzaminów doktorskich, (3) przygotowanie rozprawy doktorskiej, (4) podjęcie uchwały przez właściwą radę lub komisję doktorską (jeśli ta uchwałą danej rady została powołana) o przyjęciu publicznej rozprawy doktorskiej (przy dwóch recenzjach pozytywnych) oraz (5) uchwały o nadaniu (lub odmowie nadania) stopnia doktora (na wniosek komisji doktorskiej).

Z wnioskiem o wszczęcie przewodu doktorskiego może wystąpić osoba: (1) legitymująca się tytułem zawodowym magistra, magistra

\footnotetext{
${ }^{52}$ Rozporządzenie Rady Ministrów z dnia 16 VI 1954 r. w sprawie organizacji aspirantury naukowej dla pracujących zawodowo (Dz.U. Nr 32, poz. 129).
} 
inżyniera, lekarza lub innym równorzędnym bądź posiadająca dyplom, o którym mowa w art. 191a ust. 3 i 4 ustawy Prawo o szkolnictwie wyższym $^{53}$. W szczególnych warunkach ${ }^{54}$, określonych art. 11 ust. 3 ustawy o stopniach naukowych, także beneficjent programu "Diamentowy Grant"; (2) przedkładająca wydaną lub przyjętą do druku publikację naukową $\mathrm{w}$ formie książki lub co najmniej jedną publikację naukową $\mathrm{w}$ recenzowanym czasopiśmie naukowym objętym wykazem ministra nauki i szkolnictwa wyższego lub w recenzowanych materiałach z międzynarodowej konferencji naukowej bądź publiczną prezentację dzieła artystycznego (art. 11 ust. 2 ustawy w brzmieniu nadanym w 2016 r.).

W kwestii pierwszej autorzy założeń nie zajmują stanowiska (z wyjątkiem zespołu drugiego w odniesieniu do programu „Diamentowy Grant"55); w kwestii drugiej natomiast, przy przyjętym założeniu rozdzielności doktoratu naukowego od doktoratu zawodowego, propozycja autorów zespołu pierwszego idzie w kierunku zaostrzenia warunków wszczęcia przewodu dla doktoratów (naukowych). Ich zdaniem powinny je wypełniać wymagania: autorstwo lub istotne współautorstwo co najmniej jednej recenzowanej monografii naukowej, pracy

${ }^{53}$ Są tu możliwe dwie sytuacje. Pierwsza, gdy dyplom potwierdzający ukończenie studiów wyższych za granicą daje prawo do otwarcia przewodu doktorskiego w państwie, w którego systemie szkolnictwa wyższego działa uczelnia, która dyplom ten wydała, i druga, gdy dyplom potwierdzający ukończenie studiów wyższych prowadzonych wspólnie przez uczelnie zagraniczne daje prawo do kontynuacji kształcenia lub otwarcia przewodu doktorskiego przynajmniej w jednym państwie, w którego systemie szkolnictwa wyższego było prowadzone kształcenie. Zaistnienie każdej z tych sytuacji uprawnia do kontynuacji kształcenia na studiach trzeciego stopnia w polskiej uczelni, studiach doktoranckich w jednostce naukowej lub do otwarcia przewodu doktorskiego w polskiej uczelni lub jednostce naukowej.

${ }^{54}$ Szczególność unormowań pozwalających na odstąpienie od wymagań stawianych beneficjentom programu "Diamentowy Grant” w zakresie ogólnie wyznaczonym warunkami dla wszczęcia przewodu doktorskiego wyraża się przez dołączenie do wniosku o wszczęcie przewodu doktorskiego opinii potwierdzającej wysoką jakość prac badawczych prowadzonych przez tę osobę oraz wysoki stopień ich zaawansowania, wydanej przez opiekuna naukowego posiadającego tytuł profesora lub stopień doktora habilitowanego lub uprawnienie równoważne z uprawnieniami doktora habilitowanego, nabyte na podstawie art. 21a ustawy o stopniach naukowych i tytule naukowym oraz o stopniach i tytule naukowym w zakresie sztuki.

${ }^{55}$ Autorzy założeń tego zespołu opowiadają się za nowym określeniem zakresu podmiotowego beneficjentów programu "Diamentowy Grant” (studenci ostatniego roku studiów magisterskich) i trybu aplikacji (możliwość aplikowania w tym konkursie - przekształconym w system grantowy - przy wsparciu potencjalnych promotorów, pozwalająca na sfinansowanie ich projektów badawczych włączonych "w architekturę badań prowadzonych w danej jednostce"), Projekt drugi, s. 148, 156. 
w recenzowanym wydawnictwie zbiorowym, artykuł w kwalifikowanym czasopiśmie naukowym ${ }^{56}$. Ocena zespołu drugiego idzie natomiast w przeciwnym kierunku. Konstatując jako zbyt niskie kryteria otwarcia przewodów doktorskich, proponuje w ogóle odstąpienie od tej procedury (wszczęcia przewodu doktorskiego) w zamian za zaostrzenie rygorów oceny doktorantów w okresie odbywania studiów ${ }^{57}$.

Wedle obowiązujących przepisów nadanie stopnia doktora może obejmować osoby kwalifikowane do wszczęcia przewodu doktorskiego, po pozytywnym złożeniu egzaminów doktorskich, pracy doktorskiej (z opinią promotora) w języku polskim lub obcym za zgodą właściwej rady (wydziału, naukowej) i jej zrecenzowaniu z wynikiem pozytywnym oraz podjęciu przez właściwą radę (lub wyznaczoną komisję) stosownej uchwały. Autorzy założeń do tego zagadnienia podeszli dość wybiórczo, poza (1) podkreśleniem potrzeby oddzielenia doktoratów akademickich od zawodowych (ten pierwszy, w ocenie zespołu pierwszego, „byłby stopniem naukowym [...] stanowiąc polski odpowiednik Ph.D.", ten drugi (typu zawodowego) "byłby trzecim tytułem zawodowym [...] uzyskiwanym jako wynik przewodu "z wolnej stopy»"58) oraz (2) konkluzja, że "[d] oktorat naukowy wymagałby spełnienia warunków istotnie ostrzejszych od obecnych (i w praktyce ostrzejszych od obecnych wymagań habilitacyjnych)" ${ }^{\prime \prime}$, co nie brzmi dość jasno.

$\mathrm{W}$ istocie propozycje rozwiązań przyjętych założeniami dotyczą niektórych tylko elementów przewodu doktorskiego:

a. rozprawy doktorskiej - do wymagań stawianych rozprawom doktorskim przewidzianym prawem obowiązującym (art. 13 ustawy) autorzy założeń nie proponują zmiany. Jedynie w odniesieniu do rozpraw doktorskich prowadzących do nadania tytułu zawodowego doktora zespół pierwszy proponuje, by przesłanką nadania tego tytułu było przedstawienie oryginalnej i innowacyjnej pracy projektowej,

${ }^{56}$ Projekt pierwszy, s. 101.

${ }^{57}$ Autorzy zespołu drugiego opowiadają się za likwidacją procedury „otwierania przewodu doktorskiego" na rzecz "corocznej weryfikacji postępów w pracy (przez wewnętrzną komisję, w której skład wchodzi promotor)", Projekt drugi, s. 159.

${ }^{58}$ Przy równocześnie przyjętym założeniu: „[...] chyba że doktorant wyraziłby wolę uzyskania doktoratu akademickiego i wola taka uzyskałaby poparcie właściwej rady uprawnionej szkoły wyższej na wniosek opiekuna naukowego", Projekt pierwszy, s. 101.

${ }^{59}$ Ibidem. Potrzebę nadania doktoratom rangi obecnej habilitacji, a nawet - na najlepszych uczelniach - poziomu wyższego proponują autorzy zespołu trzeciego, Projekt trzeci, s. 120, dość niejasno propozycję tę uzupełniając słowami: „do średniego poziomu przewyższającego średni poziom obecnych habilitacji", Projekt trzeci, s. 125. 
konstrukcyjnej lub technologicznej, , w tym także np. projektu istotnego aktu normatywnego z uzasadnieniem, [...] dowodzącego znaczenia tej pracy dla danej dyscypliny (specjalności) w ramach ogólnej wiedzy teoretycznej kandydata z tej dyscypliny (specjalności)" ${ }^{\prime 60}$. Zespół drugi dodaje propozycję, by rozprawa doktorska została napisana w języku angielskim. Jest to propozycja za daleko idąca, której nie łagodzi założenie sprowadzające obowiązek dysertacji doktorskiej w angielskiej wersji językowej do wybranych dyscyplin ${ }^{61}$. Należałoby raczej optować za zachowaniem dotychczasowego rozwiązania - możliwość przedłożenia rozprawy doktorskiej w języku angielskim za zgodą właściwej rady (wydziału, naukowej), bez względu na dyscyplinę naukową. Zdecydowanego poparcia wymaga natomiast stanowisko zespołu drugiego postulującego "[z]większenie roli opieki naukowej nad doktoratem z uwzględnieniem «opieki kolektywnej» (w tym przedstawicieli instytucji otoczenia społeczno-gospodarczego)" oraz zwiększenie możliwości realizowania doktoratów międzysektorowych (doktoraty wdrożeniowe) „z inicjatywy badaczy przy wsparciu finansowania prywatnego, a nie na zamówienie firm" ${ }^{\prime 62}$;

b. recenzji doktorskich - dla rozpraw doktorskich w języku angielskim, w ocenie zespołu drugiego, co najmniej jeden $\mathrm{z}$ dwóch recenzentów rozprawy powinien być recenzentem afiliowanym $w$ renomowanej zagranicznej jednostce naukowej ${ }^{63}$. Wymóg co najmniej czterech recenzji, w tym przynajmniej dwóch spoza ośrodka przeprowadzającego przewód, postuluje zespół trzeci ${ }^{64}$;

c. zatwierdzania stopni doktorskich - przy zachowaniu uprawnienia jednostek organizacyjnych szkół wyższych (jednostek naukowych instytucji pozauczelnianych) do przeprowadzania przewodów doktorskich i nadawania stopnia doktora proponowane przez autorów zespołu pierwszego rozwiązania idą dalej, a mianowicie do zatwierdzania akademickich doktoratów naukowych przez CK. Jest to propozycja dość kontrowersyjna $\mathrm{w}$ tym sensie, że prowadzi do umocnienia stanowiska o potrzebie nadawania różnej rangi obu kategoriom doktoratów (wyższej - doktoraty akademickie i niższej - doktoraty zawodowe). Tę odmienność pogłębia także ta propozycja zespołu pierwszego, która

\footnotetext{
${ }^{60}$ Projekt pierwszy, s. 101.

${ }^{61}$ Projekt drugi, s. 159.

62 Projekt drugi, s. 159-160.

${ }^{63}$ Ibidem.

${ }^{64}$ Projekt trzeci, s. 124, 156.
} 
rezerwuje wyłącznie dla doktoratów naukowych nadanie im rangi państwowej, a nie jak dotąd dystynkcji w ramach danej jednostki organizacyjnej ${ }^{65}$.

6. Założenia są propozycją wyboru między formułą organizacyjną kształcenia na poziomie ósmym Polskiej Ramy Kwalifikacji ${ }^{66}$ : studia doktoranckie (zaproponowane przez zespoły pierwszy i drugi) a kolegium doktoranckie (zespół trzeci). Wprawdzie w obu wariantach rozwiązań są one propozycją dobrej platformy kształcenia doktorantów i ich przygotowania do pracy naukowej, to jednak tylko studia doktoranckie mocno już osadzone w strukturze szkół wyższych i jednostek naukowych skłaniają do refleksji i proponowanych zmian. Kolegium doktoranckie jest propozycją nową w polskich rozwiązaniach ${ }^{67}$.

Model studiów trzeciego stopnia wzbudza wśród autorów założeń kontrowersje o różnym natężeniu, zarówno w płaszczyźnie (1) jednostek uprawnionych do ich prowadzenia, (2) warunków dostępu do nich oraz (3) przebiegu tych studiów, stosownie do proponowanego modelu, zwieńczonego stopniem doktora (naukowego - zawodowego), jak i (4) praw oraz obowiązków doktorantów, w tym form zakładanej pomocy materialnej.

W kwestii pierwszej prawo do prowadzenia studiów doktoranckich ustawa Prawo o szkolnictwie wyższym (art. 195 ust. 1) zastrzega dla jednostek organizacyjnych uczelni oraz jednostek naukowych

${ }^{65}$ Projekt pierwszy, s. 99. Niezrozumiała jest także propozycja zespołu pierwszego, by Centralna Komisja ds. Stopni i Tytułów (albo organ kontynuujący jej obecne zadania i kompetencje) zatwierdzała doktoraty naukowe nadawane przez mniej liczebne rady lub przez rady, które wykonują w danej szkole wyższej uprawnienie do nadawania stopnia doktora, w ciągu trzech lat po jego uzyskaniu - co dodatkowo nadawałoby tym doktoratom odpowiednio wyższą rangę, Projekt pierwszy, s. 102.

${ }^{66} \mathrm{~W}$ rozumieniu Ustawy z dnia 22 XII 2015 r. o Zintegrowanym Systemie Kwalifikacji (Dz. 2016, poz. 64 ze zm.).

${ }^{67}$ Instytucja kolegium doktoranckiego w miejsce studiów doktoranckich jest propozycją autorów zespołu trzeciego. Ich zdaniem za utworzeniem kolegiów przemawiają m.in. następujące względy: prowadzenie prac naukowych w obrębie więcej niż jednej jednostki organizacyjnej uczelni, przy czynnym udziale stypendystów, doktorantów z kraju i z zagranicy z równoczesnym zapewnieniem zintegrowania ich pracy z praca doktorów rezydujących (PostDoc), wybór projektów badawczych z uwzględnieniem potrzeb cywilizacyjnych państwa, krajowej polityki naukowej i potencjału zasobu wiedzy oraz zaangażowaniem właściwych promotorów i mentorów, w tym z zagranicy, w efekcie prowadzącym do poprawy umiędzynarodowienia polskiej nauki, Projekt trzeci, s. 131-132. 
(pozauczelnianych) posiadających uprawnienie do nadawania stopnia naukowego doktora habilitowanego albo co najmniej dwa uprawnienia do nadawania stopnia naukowego doktora - w zakresie dyscyplin odpowiadających tym uprawnieniom. W ocenie autorów założeń przepis ten wymaga zmian. Pierwsza $z$ nich sprowadza się do zakresu podmiotowego, druga do stawianych nim wymagań. Autorzy dwóch pierwszych zespołów optują za prawem do prowadzenia studiów doktoranckich przez jednostki organizacyjne uczelni, i to tylko te, „które mają uprawnienia do nadawania stopnia naukowego w danym zakresie" (zespół pierwszy), w parametrycznej ocenie działalności naukowej uzyskają kategorię B-1 lub wyższą - A+, A (zespół drugi $\left.{ }^{68}\right)$, tak samo zespół trzeci ${ }^{69}$. Zarazem zespół pierwszy podnosi wątpliwość, czy w „bolońskim” systemie kształcenia prowadzenie studiów doktoranckich może być nadal domeną jednostek pozauczelnianych (instytutów naukowych PAN oraz instytutów badawczych). Konstatując to zagadnienie i pytanie, trafnie jego autorzy nie udzielają odpowiedzi twierdzącej. Nie wykluczają jednak udziału jednostek pozauczelnianych jako podmiotów współpracujących $\mathrm{z}$ daną jednostką organizacyjną uczelni w tym zakresie, „np. poprzez udostępnianie na potrzeby tych studiów laboratoriów" ${ }^{\prime \prime 7}$. I w tym też kierunku poszedł w 2017 r. ustawodawca ${ }^{71}$, aczkolwiek nie zrezygnował z prawa do prowadzenia studiów doktoranckich przez jednostki naukowe spoza uczelni ${ }^{72}$. Natomiast $\mathrm{w}$ kwestii dotyczacej prawnych wymogów odnoszących się do samodzielnego prowadzenia studiów doktoranckich stanowiska autorów projektów są podzielone. Zespół drugi, oceniając wymagania jako zbyt niskie, zdecydowanie opowiada się nie tylko za ich podwyższeniem, ale i skorelowaniem z systemem nabywania uprawnień $w$ ramach zmienionej oceny parametrycznej KEJN³7.

${ }^{68} \mathrm{~W}$ tym zakresie zespół drugi nie wyklucza także potrzeby zmiany wymagań stawianych jednostkom organizacyjnym w celu prowadzenia studiów doktoranckich przez ich ograniczenie do tych tylko jednostek, które mają prawo do habilitowania (z wyłączeniem zatem jednostek posiadających co najmniej dwa uprawnienia do nadawania stopnia doktora), Projekt drugi, s. 39.

${ }^{69}$ Projekt drugi, s. 162; Projekt trzeci, s. 118-119.

${ }^{70}$ Projekt pierwszy, s. 71.

${ }^{71}$ Ustawą z 2017 r. o zmianie ustawy o stopniach naukowych i tytule naukowym oraz o stopniach i tytule w zakresie sztuki dodano art. 5a w brzmieniu: „Kształcenie na studiach doktoranckich może odbywać się we współpracy z otoczeniem społeczno-gospodarczym uczelni albo jednostki naukowej [...]".

${ }^{72}$ Zob. dodany art. 195a ust. 2 ustawy z dnia 21 IV 2017 r.

${ }^{73}$ Projekt drugi, s. 144. 
Odmienną propozycję składają autorzy zespołu trzeciego. Postulują organizowanie (w miejsce - jak piszą - dysfunkcyjnego modelu studiów doktoranckich) kolegiów doktoranckich przez więcej niż jedną jednostkę organizacyjną dla realizacji programów doktorskich finansowanych ze środków pozyskiwanych w trybie konkursowym ${ }^{74}$.

W kwestii drugiej założenia zmierzają w stronę rewizji przepisów określających warunki i tryb prowadzenia studiów doktoranckich oraz dostępu do nich. $W$ efekcie są propozycją zmian istotnych bądź z różnym natężeniem modyfikujących dotychczasowe rozwiązania. Walor istotnej zmiany bez wątpienia cechuje oczekiwanie na odstąpienie od prowadzenia niestacjonarnych studiów doktoranckich ${ }^{75}$. Propozycję tę uzasadniają różne argumenty. Po pierwsze, odejście od umasowienia studiów doktoranckich, w znacznej mierze podyktowane pozyskiwaniem przez jednostki organizacyjne uczelni środków finansowych, co w efekcie doprowadziło do przewagi liczby doktorantów nad liczbą obronionych prac doktorskich, po drugie, dość niska efektywność w pracy nad dysertacją doktorska, po trzecie, co nie jest odosobnione, łączenie odbywania studiów doktoranckich z inną zajmującą aktywnością lub pracą zarobkową (np. w dziedzinie nauk społecznych w zakresie prawa - aplikacji prawniczych bądź asystentury w sądach powszechnych i administracyjnych, urzędach państwowych). Na zjawisko umasowienia studiów doktoranckich i potrzebę zaradzenia mu wskazują autorzy założeń trzech zespołów ${ }^{76}$.

Oparcie kształcenia na trzecim poziomie studiów wyłącznie w formie stacjonarnej stawia pytania o warunki dostępu do nich. I w tej sprawie autorzy założeń nie są podzieleni. Generalnie optują za:

(1) pozostawieniem uczelniom autonomii w zakresie kształtowania zasad rekrutacji na studia doktoranckie, ze wskazaniem na podwyższenie dotychczasowych wymagań ${ }^{77}$;

(2) ograniczeniem limitu przyjęć na stacjonarne studia doktoranckie, mierzonego wielkością kwoty zapewniającej przyjętym stypendia doktoranckie.

${ }^{74}$ Ustalenie to prowadzi autorów zespołu trzeciego także do konstatacji o możliwości odstapienia od wymogu posiadania kategorii naukowej, Projekt trzeci, s. 120.

${ }^{75}$ Projekt pierwszy, s. 90; Projekt drugi, s. 147.

${ }^{76}$ Projekt pierwszy, s. 90. Dla zaradzenia temu problemowi, w ocenie zespołu drugiego, "[o]soby niezainteresowane odbywaniem regularnych studiów doktoranckich będą mogły przygotować rozprawę i bronić ją "z wolnej stopy»", Projekt drugi, s. 144, 147; Projekt trzeci, s. 101.

77 Projekt drugi, s. 147. 
Rozwojowi naukowemu doktorantów zdecydowanie służyć będą także i te rozwiązania założeń (o ile zostaną przez prawodawcę przyjęte), które proponują:

(3) wprowadzenie, w ślad za propozycją dwumianowości doktoratów (akademickie i zawodowe), studiów doktoranckich o dwóch profilach (naukowe i zawodowe) i do nich dostosowanych efektów kształcenia ${ }^{78}$;

(4) odstąpienie od dotychczasowych warunków przyznawania stypendiów doktoranckich ${ }^{79}$ przez zapewnienie ich wszystkim doktorantom przyjętym na studia doktoranckie. Jeśli się zważy proponowaną wysokość stypendium (na poziomie co najmniej płacy minimalnej w gospodarce, waloryzowanej wraz ze wzrostem tejże płacy minimalnej) i czteroletni, tj. do ukończenia studiów doktoranckich, okres jego otrzymywania przez każdego doktoranta, to jest to dobra propozycja $z^{z m i a n y}{ }^{80}$. Zwykle bowiem doktorant poszukiwał środków na zapewnienie swojej egzystencji w zewnętrznych instytucjach zatrudniających go, nierzadko kosztem czasu potrzebnego do pracy nad rozprawą doktorską i własnym rozwojem naukowym. $Z$ drugiej strony przyznanie każdemu z doktorantów stypendium doktoranckiego bez powiązania z tym osiąganych przez niego wyników podczas studiów byłoby zaprzeczeniem równości każdego doktoranta w korzystaniu z tego prawa. Słusznie więc zespół pierwszy proponuje tu pewne obostrzenia, nie nadaje im jednak równej miary, co skłania do konstatacji o nierównorzędnym traktowaniu doktorantów. „Poza studiami, których efektem ma być doktorat zawodowy, doktorant, który uzyskał dostateczną ocenę dotychczasowej pracy, otrzymuje stypendium pomniejszone o $1 / 4^{\prime \prime}$. Tymczasem do doktorantów - uczestników studiów doktoranckich

${ }^{78}$ Projekt pierwszy, s. 90. W ocenie zespołu trzeciego uczelnie powinny zachować „pewną swobodę w kształtowaniu procedur i treści wymaganych w ramach kształcenia doktorantów [...] przy określeniu pewnych granic brzegowych określonych przez państwo (ustawowo)", Projekt trzeci, s. 123.

${ }^{79} \mathrm{~W}$ ocenie zespołu drugiego czynnikiem zniechęcającym do podejmowania kariery naukowej są obecnie obowiązujące rozwiązania. Pozwalają one bowiem na przyznawanie stypendium doktorskiego, zależnie od uczelni i dostępności środków finansowych w ramach ogólnej dotacji, osobom realizującym pełen program studiów doktoranckich niezakończonych obroną doktoratu, Projekt drugi, s. 152.

${ }^{80}$ Zespół drugi postuluje także szersze źródła finansowania stypendiów doktoranckich nie tylko ze środków centralnych ale również ze środków uczelni lub z grantów badawczych promotorów, Projekt drugi, s. 39, 151. Z kolei zespół pierwszy jest za przyznawaniem i wypłacaniem przez szkoły wyższe $\mathrm{z}$ otrzymywanych w tym celu, na jednakowych zasadach przez szkoły publiczne i niepubliczne, środków budżetowych przez okres studiów doktoranckich, Projekt pierwszy, s. 90. 
w podobnej sytuacji - adresuje rozwiązanie inne, w istocie ostrzejsze, choć nie w drodze obniżenia stypendium ${ }^{81}$;

(5) wprowadzenie zakazu pozostawania doktoranta w stosunku pracy z innym podmiotem niż szkoła wyższa, z wyłączeniem zatrudnionych na stanowisku asystenta lub stanowisku naukowo-badawczym poza uczelnią ${ }^{82}$ oraz zatrudnionych przez przedsiębiorcę lub inny podmiot uczestniczacy w programie "Doktorat wdrożeniowy";

(6) rezygnację z obowiązku prowadzenia przez doktorantów zajęć dydaktycznych, przy pozostawieniu uczelniom możliwości oferowania praktyk dydaktycznych dla kształconych doktorantów ${ }^{83}$;

(7) umiędzynarodowienie studiów doktoranckich, m.in. poprzez: stworzenie zachęt do wyjazdów zagranicznych oraz warunków ułatwiających przyjazd do Polski zagranicznym doktorantom, wprowadzenie narodowego programu szkół letnich dla doktorantów oraz przystosowanie jednostek prowadzących studia doktoranckie do przyjmowania studentów anglojęzycznych ${ }^{84}$;

(8) odstąpienie od praktyki łączenia doktoratu z gwarancją kariery w nauce, a tym bardziej od zapewnienia doktorowi stanowiska w uczelni przeprowadzającej jego przewód doktorski ${ }^{85}$.

Rozwiązania przyjęte założeniami generalnie idą w kierunku zachowania status quo form pomocy materialnej dla doktorantów. Różne jest jedynie podejście zespołów w tym zakresie. Zespół pierwszy w kwestii udziału szkół wyższych w finansowaniu i dystrybucji państwowej pomocy materialnej proponuje dwa warianty rozwiązań. Wariant pierwszy jest propozycją zachowania nagród i stypendiów naukowych dla doktorantów oraz stypendiów i innych form pomocy socjalnej finansowanych $\mathrm{z}$ budżetu państwa $\mathrm{w}$ ramach dotacji. W wariancie drugim natomiast w gestii szkół wyższych pozostałoby finansowanie nagród

${ }^{81}$ Wobec nich, po przeprowadzeniu w połowie studiów oceny dotychczasowych wyników pracy nad przygotowaniem rozprawy doktorskiej i perspektyw terminowego ukończenia studiów, zespół pierwszy proponuje: (1) w razie uzyskania oceny dostatecznej skierowanie doktoranta studiów o profilu naukowym na drogę doktoratu zawodowego, (2) przy ocenie niedostatecznej - skreślenie z listy doktorantów, Projekt pierwszy, s. 91.

82 Ibidem.

${ }^{83}$ Projekt drugi, s. 147.

${ }^{84}$ Ibidem.

${ }^{85}$ Zespół trzeci w swojej ocenie idzie także dalej, proponuje zerwanie $\mathrm{z}$ automatyzmem zatrudniania własnych doktorów mimo zachowania formuły konkursowej, Projekt trzeci, s. 120-121. 
i stypendiów naukowych ${ }^{86}$. Podobnie proponuje zespół drugi, przy czym przerzuca on ciężar wsparcia finansowego doktorantów "na rzecz wsparcia oferowanego przez uczelnie w miarę pojawiających się możliwości i potrzeb" 87 .

7. Z powyższych ustaleń rysuje się jasno, jak wrażliwa jest proponowana reforma i jej zakres, choćby wyłącznie w odniesieniu do spraw nadawania stopnia doktora i kształcenia na studiach trzeciego stopnia. Autorzy projektów założeń w odniesieniu do większości dotychczasowych rozwiązań $w$ tym zakresie zajmują stanowisko zdecydowanie krytyczne. I choć są zgodni co do zachowania stopnia doktora i prowadzenia kształcenia na studiach trzeciego stopnia, krytyce poddaja warunki i tryb udzielania uprawnień do nadawania tego stopnia, zakres wymagań stawianych $w$ przewodach doktorskich oraz warunki i przebieg studiów doktoranckich. Oczywiście, powody krytyki i w jej następstwie przedstawiane propozycje rozwiązań są różne. Uprawnienie do nadawania stopnia doktora wymaga uwzględnienia nowych propozycji w zakresie wyłonienia trzech grup uczelni, co podyktowane jest wynikami parametrycznej oceny ich działalności naukowej i w jej następstwie uzyskanej kategorii naukowej. W zakresie przebiegu przewodów doktorskich chodzi o zmianę prawnych uregulowań mających prowadzić do podniesienia wagi stopnia doktora do poziomu przynajmniej średniego obecnie uproszczonej habilitacji. Z kolei za zmianą $\mathrm{w}$ formule prowadzenia studiów doktoranckich przemawiaja, $\mathrm{w}$ ocenie autorów założeń, inne względy: ich niska efektywność, obniżana dodatkowo umasowieniem (szczególnie $\mathrm{w}$ dziedzinach nauk humanistycznych i społecznych), brak należytej współpracy między promotorem (opiekunem naukowym) a doktorantem, nadmierne obciążanie doktorantów dydaktyką, brak faktycznego powiązania zakończenia studiów doktoranckich z uzyskaniem stopnia naukowego doktora, niski poziom dysertacji doktorskich.

W jakim kierunku pójdzie ustawodawca, trudno przewidzieć. Pewne są jedynie te rozwiązania, które dotyczą doktoratów przewidzianych programem "Doktorat wdrożeniowy" - propozycji dobrej, za którą opowiadają się także autorzy trzech projektów założeñ ${ }^{88}$.

\footnotetext{
${ }^{86}$ Projekt pierwszy, s. 68.

${ }^{87}$ Projekt drugi, s. 148.

${ }^{88}$ Projekt pierwszy, s. 101; Projekt drugi, s. 33; Projekt trzeci, s. 128.
} 